\title{
Can Using a Discussion-board Enhance Writing Practice for EAP/ESL Students?
}

\author{
Fang Li \\ Xi'an International Studies University, Xi'an, China \\ Yingqin Liu \\ Cameron University, OK, USA
}

\begin{abstract}
This paper presents a case study from English for Academic Purpose II ESL class at a small public university in southwest Oklahoma, USA. The study explores the usefulness of using computer-assisted technology such as a discussion-board to improve ESL teaching and learning. The study set up two hypotheses: 1) Using a discussion board as a course platform can enhance reading and writing practice for EAP students, and 2) using a discussion board as a course platform can help EAP students receive more feedback for improving their reading and writing. To test the hypotheses, the researchers collected and analyzed the students' original and revised reading reflections and peer responses to the reflections. They also held a focus group interview among the participants to understand the students' perceptions on their reading and writing practice on the discussion board. The findings support both hypotheses. The findings show that due to some technological features of a discussion board, the EAP students obtained more additional writing opportunities than they would in a traditional classroom setting and were able to write, receive feedback, and revise more frequently and effectively. The findings also indicate that writing reading reflections and peer reviews on a discussion board motivated the EAP students to write more carefully and thoughtfully and helped them gain a sense of learning community outside the classroom.
\end{abstract}

Index Terms-EAP/ESL students, a discussion board, educational technology, ESL reading and writing

\section{INTRODUCTION}

Second language teaching professionals and researchers have noticed that, as the information and communication technologies advance, their various educational functions for promoting language teaching and learning are beingexplored and experimented on in many ESL (English as a Second language) and EFL (English as a Foreign language) classrooms. The recent research in using computer- assisted -language learning technology such as blogs and Wikis for ESL and EFL teaching has revealed some promising outcomes. For example, Hashemi \& Najafi (2011) have found that using weblogs for their Iranian EFL class not only helped the students improve their writing skills through writing more outside the class and interacting with their peers but also enabled the teachers to provide some collective targeted feedbacks for the students' writing problems. In another study, Nakamaru (2012) created a semester-long class wiki for her remedial ESL students to help them improve their English. Her study reported that the repeated out- of -class engagement through the wiki over the course of the semester led to successful outcomes (Nakamaru, 2012). However, there has been very little research done on how using a discussion board on Blackboard as a course platform can promote ESL or EFL teaching and learning.

A discussion board is an asynchronous online communication tool that allows an individual to post a comment, a reflection, or questions. Then, the other members of the same discussion board may read these postings, and respond. The Blackboard Discussion Board tool works in a similar way. It contains an interface that is composed of folders containing users' posted messages on a particular topic, threads made up of a series of responses about the same topic, and each group member's contribution to that topic. These "forums" also have many settings that control who can post and what other types of actions users can take such as editing and reposting their own threads or rating others' posts. But, one major difference of using a discussion board from other online communication tools (such as blogs) is that the discussion board is more under the control of the instructor in terms of writing topics, writing frequency, and revisions.

In order to explore the usefulness of the discussion board on Blackboard as a course platform for language teaching and learning, this paper, based on a case study for an EAP II (English for Academic Purpose) ESL class in a southwest public university in Oklahoma, USA, makes two hypotheses:

Hypothesis 1: Using the discussion board on Blackboard as a course platform can enhance reading and writing practice for EAP students and thus help improve their writing.

Hypothesis 2: Using the discussion board on Blackboard as a course platform can help EAP students receive more feedback for revising their writing. 


\section{THEORETICAL FrAMEWORK}

\section{A. Second Language Acquisition Theories}

Stephen Krashen (1981) in his Input Hypothesis claims that "an important 'condition for language acquisition to occur is that the acquirer understands (via hearing or reading) input language that contains structure 'a bit beyond' his or her current level of competence... If an acquirer is at stage or level $i$, the input he or she understands should contain $i+1$ " (p. 100). Many L2 educators believe that Krashen, in fact, advocates that language acquisition occurs through maximum exposure to comprehensible input in the target language. Swain $(1985,2005)$, on the other hand, in her Output Hypothesis, emphasizes the output, the production of the language, as a significant way to test hypotheses about the target language. She maintains that "Its role [output] is, at the minimum, to provide opportunities for contextualized, meaningful use to test out hypotheses of the target language, and to move the learner from a purely semantic analysis of language to a syntactic analysis of it" (1985, p.252). Additionally, Krashen's (1982) Affective Filter Hypothesis suggests that lowering learner stress and anxiety can improve learning conditions and make learning more fun and engaging for ESL students.

\section{B. ESL Communicative Interaction Theories and Social Constructivism}

Richard-Amato (2010) notes that Long's (1981; 1996) Interactional Hypothesis "argues that environmental contributions to the acquisition process are mediated by selective attention and the learners' processing capacity in the new language" (p. 43). Gass \& Mackey (2006), based on Long's Interactional Hypothesis, state that the "interaction approach considers exposure to language, production of language, and feedback on production as constructs that are important for understanding how second language learning takes place" (p. 3). Indeed, the social constructivism represented by cultural-historical activity theory also maintains that knowledge is constructed through social interaction such as conversation, discussion, and negotiation process (as cited in Kuo, Belland, \& Kuo, 2017). Vygotsky (1978) also claims that learning happens through meaning making that involves the process of sharing various perspectives and experiences in communities of practice.

\section{The Rationales on Writing Reading Reflections}

Smith (2010) and Atwell (1987) claim that students learn to read by reading and learn to write by writing while Zamel (1992) and Spack (1985) argue that, when ESL learners are given opportunities to connect their reading and writing activities, their language learning will be enhanced. Additionally, Lee (2015) also sees the connection between the reading and writing and states that "[among] the various reading and writing activities, keeping a reading response journal has long been viewed as a vital tool to engage students in both learning activities" (p.111). In fact, the literature on writing reading reflections summarizes three advantages: 1) helping students gain the meaning from the reading (Hurst 1999 \& Rossing, 2009), 2) making students use writing to clarify, organize, and express thoughts from their reading (Cohen, 2007), and 3) providing an opportunity for students to find effective reading and writing strategies and communicate with peers (Leki, 2001).

The insights drawn from these theories for this study is that doing more reading (receiving comprehensive input) and writing (producing language output) in the second language with constant teacher and peer feedback (involving social interactions) will provide more English language learning opportunities and interactive communication for the EAP and ESL students. Informational technology, however, as a medium for communicative interaction, can help expand these opportunities for ESL learners' genuine and meaningful communication in the target language (McClanahan, 2014). Applying technology such as the discussion board into ESL classrooms should promote the second language acquisition/learning in all the four language skills, especially in reading and writing.

\section{METHOD}

\section{A. Participants}

This paper presents a case study that lasted 8 weeks. Five ESL students taking English for Academic Purposes II (English 0413) in the spring 2014 semester at a small public university in Oklahoma, USA participated in the study. Those students were from five different countries: Paraguay, Spain, Germany, South Korea, and Mongolia.

\section{B. Research Settings}

At the university, EAP II was a remedial writing class designed for ESL students as a transition/prerequisite class to the university freshman composition class (English 1113). The EAP II class met 75 minutes twice a week. The course objectives of the EAP II (created by one of the researchers, the instructor of EAP II) mainly focused on:

1) Writing: Students will be able to construct clear thesis statements; to understand essay development and structures, to write unified, coherent essay focused on different patterns of development; and to write five- paragraph essays,

2) Reading: Students will be able to understand main idea, analyze supporting ideas, and summarize the main ideas, and

3) Grammar and Mechanics: Students will be able to refine knowledge and skills of using correct words, sentence structures, and punctuation. 
To fulfill the course objectives, two textbooks were used to facilitate the learning: One was focused on reading, and the other was on writing.

At the beginning of the semester, through assessing the student diagnostic writing and giving individual conferences with the students, the researchers identified some special academic needs of these students in this class:

a. To have more reading and writing practice to enrich their writing invention experiences, understand usages of English grammar, and express themselves fluently and correctly,

b. To receive more feedback from their instructor and peers for improving their reading and writing,

c. To revise more to understand the nature of their errors in their writing.

\section{Procedures}

During the beginning of the spring semester in 2014, the students were assigned one of the major assignments of the course: Reading Reflection Postings to the Discussion Board on the course website- Blackboard. The reading reflections were based on the reading chapters in their textbook Cover to Cover 3: Reading Comprehension and Fluency. The assignment asked them not only to post their reflections but also to revise and repost each reflection based on the individual written feedback from the instructor and their peers. Additionally, they were also required to post their peer responses on the Discussion Board for their classmates' original postings.

At the end of the semester, a focus group interview (see Appendix 1) was given to all the participants by the instructor (one of the researchers) to understand their opinions about their writing practice on the Discussion Board.

\section{Data Collection}

Two types of data were collected:

a. the students' original reading reflections, revised reading reflections, and peer response postings on the Discussion Board, which aimed to see the frequency of the writing and its effect on writing;

b. the results of the focus group interview, which aimed to understand students' perceptions of the effectiveness of writing the Discussion Board.

\section{FINDINGS AND DISCUSSION}

This section will present the findings of and discussion on the study in response to the two hypotheses presented in the beginning and will discuss the significance of the findings.

Hypothesis 1: Using discussion board as a course platform can enhance reading and writing practice for EAP student and thus help improve their writing.

The findings about the postings on the discussion board showed that, throughout the eight weeks of the semester, the participants had written 4 original reading reflections and 4 revised reading reflections (based on the instructor's and the peers' feedback) on the discussion board. There were 25 peer responses (some students responded to more than one classmate's reflection in each posting). When we compared these results with the previous semester (Fall 2013 where we did not use a discussion board), the writing reading reflection postings in this study could be seen as "extra writing practice opportunity" the participants had in their target language learning.

One of the major reasons for the students to have this "extra-writing practice opportunity" or to be able to write more frequently via using the discussion board was obviously due to some key technology features of the discussion board. In this class, students could access the discussion board through a course link inside a learning module--Blackboard, a type of educational software and purchased and installed by the university for students and faculty. In fact, they could access the discussion board at any location and any time at their own convenience as long as there was an internet connection. During and after their production of reading reflections, they could also edit and repost the same drafts, and thus it provided students with an additional online learning space to revisit their thinking and writing process easily. As the educators at the University of Arizona note, through discussion boards, "[students] have time to reflect on what [they] want to say before [they] enter [their] responses in the system. They are also able to view the responses and perspectives of all [their] classmates, which is not easily accomplished in a real classroom setting" (Online discussions).

After all, the significance of being able to write more frequently and conveniently via using a discussion board lies in several aspects. According to Swain (1985), using the target language to communicate not only can provide ESL/EFL students opportunities to test out hypotheses of the target language, but also it can move the learners from "a purely semantic analysis of language to a syntactic analysis of it" (p. 252). That is to say, in the EAP students' learning context here, the students would first focus on their reading comprehension on the assigned reading chapters, which involved using and expanding their knowledge of English vocabulary, expressions, and grammar. As a result, they practiced receiving and understanding meaning of language input as what Krashen (1982) claimed in his Input Hypothesis. Then, in order to write the reflection, they needed to shift not only to generate various English sentence patterns with proper vocabulary and grammar but also to demonstrate their understanding on writing paragraphs and essays, thus further practicing using English language through producing output. Therefore, the discussion board here served as a learning space for EAP students to practice reading and writing in English more frequently and helped them to become better writers. 
Table 1 compares the sample reading reflections of the students during the eight week period, which shows that the students improved their writing mainly in the areas of clarity of meaning, sentence coherence (through using transitions), and correct grammatical usage.

TABLE 1

COMPARISON OF SAMPLES OF EAP I STUDENT READING REFLECTIONS

\begin{tabular}{|c|c|c|}
\hline $\begin{array}{l}\text { The Selected } \\
\text { Student Reading } \\
\text { Reflections }\end{array}$ & The Original Reflections & $\begin{array}{l}\text { The Revised Reflections (based on the feedback from } \\
\text { the instructor and the peer responses and the revised } \\
\text { parts were underlined) }\end{array}$ \\
\hline $\begin{array}{l}\text { Reflection } 1 \\
\text { ( Student } 1 \text { ) }\end{array}$ & $\begin{array}{l}\text { "In this lecture I could notice many things that I did not } \\
\text { know about the stress; like a is not only a but thing. I } \\
\text { realize now that the stress is similar that a warning, that } \\
\text { our body makes on purpose, so this is very useful for } \\
\text { us. There stress likely is manageable, it means that you } \\
\text { can have control of the stress, but you can eliminate. } \\
\text { There are strategies that you can use to control the } \\
\text { stress or reduce the intensity of it; this strategies are for } \\
\text { instance: take waks, relaxion techniques, do yoga. } \\
\text { Everybody knows which technique is better for his } \\
\text { own body you can choose many. In my case I try to } \\
\text { talk with my friends, take a long walk without cell } \\
\text { phone, I do not want to know what time is it, I only } \\
\text { want to walk alone. Finally I can say that the stress is a } \\
\text { big tool for our bodies. It is imposible to make a lot of } \\
\text { things in a certain amount of time, you need to take a } \\
\text { rest or make something that help you to out of the } \\
\text { routine. For me the best way to interact or reduce the } \\
\text { stress is if you are organize and choose priorities for } \\
\text { each day, making a process, step by step. At the end I } \\
\text { found a very useful alarm warning that help me at all." }\end{array}$ & $\begin{array}{l}\text { "In this reading, I have noticed many things that I did } \\
\text { not know about the stress; for example, it is not just a } \\
\text { bad thing. I've realized now that the stress is similar to a } \\
\text { warning that our body makes to us on purpose, so this is } \\
\text { very useful for us. The stress luckily is manageable, and } \\
\text { it means that you can have control of the stress, but you } \\
\text { cannot eliminate it. There are strategies that you can use } \\
\text { to control the stress or reduce the intensity of it; these } \\
\text { strategies are for instance: taking walks, learning } \\
\text { relaxing techniques, and doing yoga. Everybody knows } \\
\text { which technique is better for his or her own body; you } \\
\text { can choose many. In my case, I try to talk with my } \\
\text { friends, and take a long walk without cell phone. I do } \\
\text { not want to know what time it is, and I only want to } \\
\text { walk alone. Finally, I can say that the stress is a big } \\
\text { signal our body gives to us. It is impossible to make a lot } \\
\text { of things in a certain amount of time, so you need to take } \\
\text { a rest or do something that helps you to be out of the } \\
\text { routine. For me, the best way to interact with or reduce } \\
\text { the stress is that I try to organize myself and choose } \\
\text { priorities for each day, making a plan, and doing things } \\
\text { step by step. In the end, I found a very useful alarm } \\
\text { warning, so the stress also helps me a lot." }\end{array}$ \\
\hline $\begin{array}{l}\text { Reflection } 2 \\
\text { ( Student 2) }\end{array}$ & $\begin{array}{l}\text { "There are several reasons to why teenagers are easily } \\
\text { to get obesity. One cause is stress among teenagers. } \\
\text { Now days, teenagers get lots of stresses from many } \\
\text { things. It could be from their school grade, friendship, } \\
\text { or etc. If human gets too much stresses then the brain } \\
\text { stimulate some nerves and that make people to eat a } \\
\text { lot. Second, fast foods could be another reason. We can } \\
\text { so easily find McDonald, Burger King, Taco Bell, or } \\
\text { etc. in everywhere, and those foods are very high } \\
\text { calorie, which means easy to get obesity than other } \\
\text { foods. Lastly, technology may causes of obesity. On } \\
\text { the earth now we have very high technology, and many } \\
\text { people have at least one of their own smartphone or } \\
\text { game devices, for examples, X-Box, Wii, and } \\
\text { Nintendo. Instead, people do exercise, they always } \\
\text { stick with their game devices, and it causes people not } \\
\text { move, exercise, and less spending energy." }\end{array}$ & $\begin{array}{l}\text { "There are several reasons for why teenagers are easily } \\
\text { to get obesity. One cause is stress among teenagers. } \\
\text { Nowadays, teenagers get lots of stresses from many } \\
\text { things. It could be from their school grade, friendship, or } \\
\text { etc. If human gets too much stresses then the brain } \\
\text { stimulates some nerves and that makes people to eat a } \\
\text { lot, thus making a person put on weight. Second, fast } \\
\text { foods could be another reason. We can so easily find } \\
\text { McDonald, Burger King, Taco Bell, or etc. everywhere, } \\
\text { and those foods are in very high calorie, which means it } \\
\text { is easy for people to get obesity than other foods. Lastly, } \\
\text { technology may cause obesity. In the world now, we } \\
\text { have very high technology, and many people have at } \\
\text { least one of their own smart phone or game devices, for } \\
\text { examples, X-Box, Wii, and Nintendo. Instead of doing } \\
\text { exercise, people always stick with their game devices, } \\
\text { and it causes people not to move, exercise, and spend } \\
\text { less energy. So these are the reasons why teenagers get } \\
\text { obesity easily." }\end{array}$ \\
\hline $\begin{array}{l}\text { Reflection } \\
\text { 3( Student 3) }\end{array}$ & $\begin{array}{l}\text { "The Day of the Dead (dia de los muertos) is a } \\
\text { celebration that is celebrated thru most Latin countries. } \\
\text { In Mexico it is celebrated around the } 1^{\text {st }} \text { and } 2^{\text {nd }} \text { day of } \\
\text { November. It is a national holyday in my country; } \\
\text { traditionally we remember those that had died in our } \\
\text { families or friends. The celebration includes walking } \\
\text { from our homes to the cemetery where our loved ones } \\
\text { are buried. Another traditional thing we do is we } \\
\text { prepared the person/s favorite meal to take as tribute to } \\
\text { them, we often sees death as just a cycle of life. The } \\
\text { festival also includes customary deserts and other } \\
\text { foods and artifacts. They make a special kind of bread } \\
\text { dubbed bread of the dead(pan de muertos) and also } \\
\text { they make skull candies made with sugar cane. } \\
\text { Although it is a tragedy to lose our friends and family } \\
\text { we take a special day to remember them in life, when } \\
\text { we go to the cemetery we sit down clean their } \\
\text { tombstones and we even eat a meal in the cemetery. } \\
\text { The reason why this festival is so interesting is because } \\
\text { in that day we truly are connected to our loved ones } \\
\text { even though they have passed on." }\end{array}$ & $\begin{array}{l}\text { "The Day of the Dead (dia de los muertos) is a } \\
\text { celebration that is celebrated through most Latin } \\
\text { countries. In Mexico, it is celebrated around the } 1^{\text {st }} \text { and } \\
2^{\text {nd }} \text { day of November. It is a national holyday in my } \\
\text { country; traditionally we remember those that had died } \\
\text { in our families or friends who passed away. The } \\
\text { celebration includes walking from our homes to the } \\
\text { cemetery where our loved ones are buried. Another } \\
\text { traditional thing we do is that we prepared the person/s } \\
\text { favorite meal to take as tribute to them we often see } \\
\text { death as just a cycle of life. The festival also includes } \\
\text { customary deserts and other foods and artifacts. People } \\
\text { make a special kind of bread dubbed bread of the dead } \\
\text { (pan de muertos), and also they make skull candies made } \\
\text { with sugar cane. Although it is a tragedy to lose our } \\
\text { friends and family, we take a special day to remember } \\
\text { them in life. When we go to the cemetery, we sit down } \\
\text { and clean their tombstones, and we even eat a meal in } \\
\text { the cemetery. The reason why this festival is so } \\
\text { important is because on that day we truly are connected } \\
\text { to our loved ones even though they have passed away." }\end{array}$ \\
\hline
\end{tabular}


The focus group interviews also revealed that the students reported spending more out- of -class time on reading and writing because of the discussion board postings. One student said that 'I edited my grammar more carefully with my reflections because I didn't want my classmates to be confused with my writing.' Another student mentioned that 'since we all responded to the same readings on discussion board, I tried to read each of the reading several times before I started to write so that I could say something interesting and special about the article.' This finding of students' giving more time to reading and grammar seems to concur with Lee's (2012) idea on the reading response e-journal. Her research shows that using the reading response e-journal serves as an alternative way to engage low-achieving EFL students because the reading response offered students a means of articulating, exploring, and expanding their understanding on the reading (Lee, 2012). Furthermore, Lee's study concludes that "[w]hen journal writing becomes a consistent part of students' learning, it motivates them to write more in length and richer in context" (2012, p.113). Similarly, the students in this study seemed to become motivated and interested in doing the reading reflections during this eight-week period; thus, they put more effort into this learning experience.

We can say that the findings so far support "Hypothesis 1: Using discussion board as a course platform can enhance reading and writing practice for EAP students and thus to help improve their writing."

Now, we will report and discuss the findings for second hypothesis:

Hypothesis 2: Using discussion board as a course platform can help EAP students receive more feedback for revising their writing.

This second hypothesis was also supported by both findings on the frequency of postings and on the focus group interview. Each student received a total of 4 feedback responses for his or her four original reading reflections from the instructor and at least 20 written feedbacks from his or her peers for the same four original reflections throughout the eight weeks. Based on all the feedbacks, each participant revised each reflection and then repost it to the discussion board to be re-graded by the instructor and re-read by the peers.

Thus, it is obvious that the students received more feedbacks for their original postings than they would be if they simply had the reading reflections for in-class workshops as they did for the other three major essays. In a workshop, due to the time limit, each student usually only had enough time to peer review one classmate's essay, so each student could only get one peer feedback. In contrast, on the discussion board, since there was no time and location restriction, it was much more efficient and convenient for each student to read other peers' postings and respond to them.

The importance of peer responses for ESL students has been emphasized by many scholars. Mittan (1989) states that peer feedback is a way of giving control to students since it allows them to make active decisions about whether or not to use their peers' comments as opposed to a passive reliance on teachers' feedback. Moreover, since student reviewers may perceive that their peers might experience the similar difficulties in writing as they do, peer feedback may actually help to reduce writer anxiety and increase writer confidence (Chaudron, 1984). More importantly, peer feedback can benefit both the reviewers and the writers by helping them to have a specific audience (their classmates) in their minds (Hyland, 2014); thus, their feedback might be more easily understood and applied to the revisions. So, with the increased peer response practice due to using the discussion board, the EAP students also have benefited from the advantages peer responses can offer.

In fact, the focus group interview showed that the students held very positive attitudes towards the roles of the peer feedback played in revising their reading reflections. For example, one student said, 'I like to read my classmates' comments because I can feel that they are honest with me and truly want to help me.' Another student claimed that 'one thing I enjoyed using my peers' feedback is that they made me excited about what I did well even though sometimes I was a bit upset with their corrections on my errors.' Still, some students remarked that one thing that really benefited them was the process of writing the peer responses itself because they believed that it helped them become both a more careful reader and writer. As one of them explained, 'You know if you want to give others some good suggestions, you really need to understand what they are saying and help them find out their mistakes. So, I often spent a lot of time to write my peer responses and to show I am serious about my classmates' writing and want to share my opinions with them.'

In the following, Table 2 displays some samples of student peer responses, which demonstrates how the students tried to help each other in the aspects of encouragement, appreciation of others' cultures, and constructive critiques. 
TABLE 2

SAMPLE EAP STUDENT PEER RESPONSES

\begin{tabular}{|c|c|c|}
\hline $\begin{array}{l}\text { The Summary of } \\
\text { the Themes of the } \\
\text { Peer Responses }\end{array}$ & Sample Student Peer Responses (1) & Sample Student Peer Responses (2) \\
\hline $\begin{array}{l}\text { Encouragement for } \\
\text { each other }\end{array}$ & $\begin{array}{l}\text { "It was easy to understand for me because of your outline. I am totally } \\
\text { agreed with your first cause of teenager's obesity. First, I did not think } \\
\text { about teenager's parent's influence, but after you guys opinion I } \\
\text { realize it can be most reason for teenager's obesity especially for } \\
\text { Americans because they love to eat fast foods and frozen foods." } \\
\text { ( Student 3) }\end{array}$ & $\begin{array}{l}\text { "I think it is really interesting what you are saying } \\
\text { about how role models can give hope to the other } \\
\text { people. I have the same opinion than you about } \\
\text { this topic, people should help each other to make } \\
\text { a better world" (Student } 2 \text { ). }\end{array}$ \\
\hline $\begin{array}{l}\text { Appreciation of } \\
\text { each other's } \\
\text { cultures }\end{array}$ & $\begin{array}{l}\text { "I have notice that in your country, your people celebrated also that. } \\
\text { In my country is the same thing. It is true that this is a custom most } \\
\text { commonly in the latin american countries. However there are } \\
\text { differences in how we celebrated in my country. I noticed that in your } \\
\text { country this is an very important day, even you has a holiday for that. } \\
\text { In Paraguay there are only a few of persons that celebrated the day of } \\
\text { deads, and it is only in the small cities and little towns. This is } \\
\text { because in my country those places are the places that until now have } \\
\text { a lot of custom and beliefs. I liked see that in latin america we have a } \\
\text { few celebrations in common. Finally I want to say that I liked how } \\
\text { your people has until now that tradicions also how they celebrated this } \\
\text { day" ( Student 1). }\end{array}$ & $\begin{array}{l}\text { "It is intereting that you give examples that how } \\
\text { male beauty works in Korea. Also it is a really } \\
\text { helpful information to let people know that how } \\
\text { male beauty becomes a trend in different } \\
\text { countries. I totally agree with you, because in } \\
\text { Mongolia, most of guys started to care about } \\
\text { themselves, which is a good thing. For me, good } \\
\text { looking men are always seem to be more } \\
\text { confident with themselves" (Student } 3 \text { ). }\end{array}$ \\
\hline $\begin{array}{l}\text { Constructive } \\
\text { Critique }\end{array}$ & $\begin{array}{l}\text { "I did not see anything about your opinion. Reflection should base on } \\
\text { your opinion or your thought after read story or something. I think } \\
\text { you just summarized what was story about so I hope just add some } \\
\text { your opinion and your own experiences as an example so we can } \\
\text { understand what you felt after read this passage" (Student 4). }\end{array}$ & $\begin{array}{l}\text { "I like the sound of that festival. It sounds like it } \\
\text { involves a lot of activities. It is great that they } \\
\text { keep that tradition alive, it is important to } \\
\text { remember our history so that we not repeat the } \\
\text { mistakes from the past. Is there a fun story about } \\
\text { the festival that you would like to share with me? } \\
\text { I would love to listen to it. I also would like to tell } \\
\text { you that please watch out for run-on sentences. } \\
\text { They are confusing to me. I know I also make } \\
\text { errors on it" (Student 5). }\end{array}$ \\
\hline
\end{tabular}

These findings from the focus group interview and sample peer responses in Table 2 seem to echo Cuhadar's \& Kuzu's (2010) research finding: using technological tools such as blogs in constructivist learning environments can provide learners the means to cooperate and interact with peers from different cultures, seek and share information, and solve problems and make decisions (as cited in Kuo, Belland, \& Kuo, 2017). The findings also indicate that using the discussion board had helped the EAP students attain a sense of learning community outside the classroom. According to McMillan \& Chavis (1986), when group members feel that other members matter to one another and to the group and when group members' goals and needs can be met through their commitment to be interactive with and responsible for one another, the sense of community or belongingness among the members is established. This sense of learning community seems to have formed among the EAP students. With this creation of a learning community for the EAP students in mind, we can better understand how and why the EAP students appeared more engaged in peer reviews and responses on the discussion board.

\section{CONCLUSION AND IMPLICATIONS}

This eight-week case study on using a discussion board to enhance the EAP students' reading and writing practice turned out to be rewarding for both ESL teaching and learning. Taking advantage of the discussion board, we were able to expand the exposure of the target language to the EAP students and thus help them receive more comprehensive input (Krashen, 1982) from reading chapters, from instructor feedback, and from peer feedback. Additionally, using the discussion board as a teaching and learning tool, we were also able to engage students in doing more productive interaction with the target language and with the peers through frequently writing, revising, and reviewing others' work. We suggest that the students not only have more practice in receiving language input but also on generating language output (Swain, 1985). Still, using the discussion board as a teaching tool enabled us to scaffold the students' learning by allowing us to post some specific instructions for the students on how to approach different reading reflection assignments (see Appendix 2). Finally, the study also shows that the students subconsciously established a learning community within themselves outside their classroom through meaningful interacting with one another on the discussion board, in which they cared about each other, helped each other, and encouraged each other.

Despite these positive findings, we noticed that the public nature of writing on the discussion board may cause some unexpected anxiety among some EAP students. For instance, two students admitted that writing reading reflections on discussion board sometimes made them a bit upset because they worried about they might lose face or appear silly if they made many errors in their writing. This awareness of their limited English proficiency, however, may work as a double edge sword. On one hand, it would make the students feel pressured and ultimately treat writing on the discussion board as a burden. On the other hand, to consider saving face, the students would also work very hard to improve their English and do a good job. The similar situation also occurred in other studies. Lin, Groom, \& Lin (2013) 
in their article, "Blog-assisted learning in the ESL writing classroom: A phenomenological analysis," claim that "[t]he students' awareness of a large and potential critical audience for their work and their anxiety about grammatical mistakes did not affect the amount of effort they put into their writing, however" (p. 134). The implication from this kind of phenomenon would be that ESL instructors need to realize that using teaching strategies to help lower ESL learner stress and anxiety in an online learning environment due to its exposure to public can be more urgent and challenging than those in a traditional classroom.

\section{APPENDIX 1. FOCUS GROUP INTERVIEW QUESTIONS}

1. How do you like the writing reading reflections on discussion board?

2. What do you see as the advantages of posting your reading reflections on discussion board?

3. What are the things you like about writing peer responses on discussion board?

4. What are the things you dislike about writing peer responses on discussion board?

5. In what ways, do you think that writing and revising reading reflections and writing peer responses have helped improve your writing?

\section{APPENDIX 2. THE INSTRUCTOR's SAMPLE INSTRUCTIONS FOR WRITING READING REFLECTIONS}

Instruction: In this reading reflection 1, please write one well -structured paragraph of about 350 words on "Male Beauty" or on "Changing Faces." Make sure that you will establish a clear topic sentence (which tells the main idea of your paragraph) and support it with adequate detailed explanations and examples. In your paragraph, please also try to use various sentence types ( such as simple sentences, compound sentences, and complex sentences) to make your paragraph more effective and interesting.

Instruction: In this reading reflection 3, please write a short essay that will

- first write an introduction to provide background information and introduce your thesis statement,

- then, summarize the article " A Role Model Makes a Difference" from Cover to Cover 3 Unite 6, Part 2,

- next, reflect on the article ( discussing what you think of the ideas in the article or what you've learned from the article), and

- finally, write a concluding paragraph for your essay.

\section{REFERENCES}

[1] Atwell, N. (1987). In the middle: Writing, reading, and learning with adolescents. Portsmouth, NH: Heinemann.

[2] Chaudron, C. (1984). The effects of feedback on students' composition revisions. RELC Journal, 15, 1-15.

[3] Cohen, J. (2007). A case study of a high school English-language learners and his reading. Journal of Adolescent \& Adult Literacy, 51, 164-175.

[4] Gass, S. \&Mackey, A. (2006). Input, interaction and output. AILA Review, 19, 3-17.

[5] Hashemi, M. \& Najafi, V. (2011). Using blogs in English language writing classes. International Journal of Academic Research, 3(4), 599-604.

[6] Hurst, B. (1999). Living learning logs. The Journal of Reading Education, 24, 37-41.

[7] Hyland, F. (2000, Jan.) ESL writers and feedback: Giving more autonomy to students. Language Teaching Research, 4(1), 3354.

[8] Krashen, S. (1982). Principles and practice in second language acquisition. Oxford: Pergamon Press.

[9] Krashen, S. (1985). The input hypothesis. London: Longman.

[10] Kuo, Y.C., Belland, B. R., \& Kuo, Y.T. (2017). Learning through blogging: Students' perspectives in collaborative blogenhanced learning communication. Educational Technology \& Society, 20 (2), 37-50.

[11] Lee, H. C. (2012). The reading response e-journal: An alternative way to engage low-achieving EFL students. Language Teaching Research, 17(1), 111-131.

[12] Leki, I. (2001). Reciprocal themes in ESL reading and writing. In T. Silva \& PK Matsuda (Eds.), Landmark essays on ESL writing (pp.173-190). Mahwah, NJ: Hemagoras Press.

[13] Lin, M.H., Groom, N., \& Lin, C.Y. (2013). Blog-assisted learning in the ESL writing classroom: A phenomenological analysis. Journal of Educational Technology \& Society, 16(3), 130-139.

[14] Long, M. (1981). Input, interaction, and second language acquisition. In H. Winitz (Ed.), Native language and foreign languages acquisition: Annals of the New York Academic of Sci3ence.

[15] Long, M. (1996). "The role of the linguistic environment in second language acquisition." In W. Ritchie \& T. Bhatia (Eds.), Handbook of second language acquisition (pp. 413-468). San Diego: Academic Press.

[16] McMillan, D. W., \& Chavis, D.M. (1986). Sense of community: A Definition and theory. Journal of Community Psychology, $14,6-23$.

[17] McClanahan, L. (2014). Training using technology in the adult ESL classroom. MPAEA Journal of Adult Education, 43(1), 2227.

[18] Mittan, R. 1989: The peer review process: harnessing students' communicative power. In D. Johnson \& D. Roen (Eds), Richness in writing: Empowering ESL students (pp.207-219). New York: Longman.

[19] Nakamaru, S. (2012). Investment and return: Wiki engagement in a "remedial" ESL writing course, JRTE, 44 (4), $273-291$.

[20] Online discussions: An overview. http://ualr.edu/blackboard/welcome/how- to/discussions/\#discuss_overview (accessed $18 / 6 / 2017)$. 
[21] Richard-Amato, P. A. (2010). Making it happen: From interactive to participatory language teaching: Evolving theory and Practice $4^{\text {th }}$ ed. White Plain, NY: Pearson/Longman.

[22] Rossing, L.J. (Ed.) (2009). The write to read: Response Journals that increase comprehension. Thousand Oaks, CA: Corwin Press.

[23] Smith, F. (2010). Understanding reading: A psycholinguistic analysis of reading and learning to read (6thed.). New York: Routledge.

[24] Spack, R. (1985). Literature, reading, writing, and ESL: Bridging the gap. TESOL Quarterly, 19, 703-725.

[25] Swain, M. (1985). Communicative competence: Some roles of comprehensive input and comprehensible output in its development. In S. Gass \&C. Madden (Eds). Input in second language acquisition (pp235-253). Rowley, MA: Newbury House

[26] Swain, M. (2005). The output hypothesis: Theory and research. In E. Hinkel (Ed). Handbook of research in second language teaching and learning (pp471-483). Mahwah. NJ: Lawrence Erlbaum.

[27] Vygotsky, L.S. (1978). Mind in society: The development of higher psychological process. Cambridge, MA: Harvard University Press.

[28] Zamel, V. (1992). Writing one's way into reading. TESOL Quarterly, 26, 463-485.

Fang $\mathbf{~ i i ~ i s ~ a ~ l e c t u r e r ~ a t ~ S c h o o l ~ o f ~ T r a n s l a t i o n ~ S t u d i e s ~ a t ~ X i ' a n ~ I n t e r n a t i o n a l ~ S t u d i e s ~ U n i v e r s i t y , ~ C h i n a . ~ H e ~ o b t a i n e d ~ a ~ P h . D . ~ d e g r e e ~}$ in Instructional Leadership from the University of Alabama, USA, with a concentration in instructional technology in 2016. He also received his MEd in Literacy/TESL in 2008 from University of Cincinnati, USA. His current research interests and primary practice include: computer-assisted translation, localization, teaching translation and interpretation with VR (virtual reality) and AR (augmented reality), multimedia courseware development, and mobile learning

Yingqin Liu is an Associate Professor in the Department of English and Foreign Languages at Cameron University, Lawton, Oklahoma, USA. She was granted a doctoral degree in Technical Communication and Rhetoric from Texas Tech University in 2007. Her major research interests are in the theories and practice of intercultural communication and intercultural rhetoric, second language teaching and writing, and technical/ business communication. She has published articles in these areas. 